\title{
Fidelidade ao Bom Senso
}

\author{
Max Grinberg
}

São Paulo, SP

Anamnese e exame físico, alguém imagina que algum dia eles poderão deixar de existir? Ninguém certamente, a prática médica sempre permanecerá fiel à escuta da história, inspeção, palpação, percussão e ausculta.

Todavia, fidelidade como a virtude do mesmo, daquilo que resiste apesar do tempo, não exclui renovações, pois o que dura é o que se adapta a novas realidades e exige esquecer aquilo que não mais cabe, que, agora, até prejudicaria a sobrevivência.

Este enfoque é especialmente válido para a propedêutica clínica que nestes últimos tempos tem sido desafiada pelo grande avanço da tecnologia aplicada, apoiada particularmente na imagem.

O clínico - tanto o generalista quanto o especialista exerce sua cotidiana missão buscando harmonizar o uso direto (e clássico) e indireto (através de imagens, por exemplo) dos próprios sentidos, e por que não dizer, sensível ao polêmico sexto sentido.

Não são oportunas posições nem de iconoclasta nem de adorador de exames. Em outras palavras, cabe fidelidade à semiologia clássica sem a hipocrisia de lhe atribuir limites infinitos.

Como a rotina na aplicação de métodos não é exatamente sinônimo de seqüência imutável de ações, anamnese e exame físico toleram modificar ou mesmo dispensar certas práticas para conservar sua força, porque novas técnicas compensam com maior precisão: palpação dos rins, percussão do precórdio, pesquisa dos vários pontos renais, como é mesmo que se faz?

Comecemos (como praxe) pela anamnese, patrimônio inalienável da relação médico-paciente. A sua condução é ato de verdadeira garimpagem de valores sob influências variáveis da razão e da emoção, amalgamando posições egoístas e altruístas na exata medida da percepção mútua entre o que se pretende que seja ouvido e que seja dito.

É exercício de criatividade harmonizar o clássico e a alta velocidade do progresso na área médica, e preservar segura a anamnese. Em outras palavras, é imperioso conciliar espírito acadêmico, supressão de itens nunca preenchidos e acréscimos ditados pelo surgimento de novas doen-

Instituto do Coração do Hospital das Clínicas - FMUSP

Correspondência: Max Grinberg - Incor - Equipe de Cardiopatias Valvares - Av. Dr. Enéas C. Aguiar, 44 - 05403-000 - São Paulo, SP

Recebido para publicação em 2/10/97

Aceito em 28/10/97 ças e novos conhecimentos. Certamente, consenso é improvável, mas o empenho na tarefa se justifica, afinal talvez valha mais esquecer, que um paciente com 60 anos de idade chorou ao nascer, e se preocupar com outrora tabus como certos hábitos e vícios.

O fator tempo tem sido considerado cada vez mais e, por isso, a anamnese de certa forma resulta abreviada. Nada inaceitável, desde que seja mantido o propósito: obtenção fidedigna da história clínica pela verbalização livre, a partir da queixa principal, enriquecida pelo diálogo (interlocutores sempre procurando utilizá-lo na exata reciprocidade de se ter uma boca e dois ouvidos).

Não se pode exigir que o paciente esteja treinado para uma correta exposição linear dos acontecimentos e na sua exata valorização clínica; a situação aflitiva de momento pode privilegiar emoções em detrimento da razão e causar turbulências na ordem ideal da comunicação. Por isso, é indispensável promover redirecionamentos através de perguntas estratégicas, tanto das orientadas pela exposição, quanto das habitualmente formuladas independentemente da história (interrogatório complementar).

A necessária dimensão das informações pode não estar pronta na clássica primeira abordagem e, assim, a anamnese admite diversidade de momentos em prol da autenticidade. Conseqüentemente, tolera distintos processos de emitir, transmitir e receber mensagens.

Oexame físicoé, por exemplo, momento onde se reabre o diálogo. A identificação de certos sinais torna necessário saber sobre certos sintomas não informados, ou repassar os já conhecidos, e assim ir esculpindo o diagnóstico clínico.

Nãoé incomum o paciente declarar "um esquecimento" ao final da consulta, após saber aliviado que nada de anormal foi clinicamente identificado; pode ser o momento em que surge o verdadeiro motivo da consulta, que faz se repensar sobre solicitação de exames complementares, ou mesmo, promover uma volta imediata ao exame físico.

A ocasião da consulta de retorno, em que barreiras iniciais podem já ter sido quebradas, também se presta a complementos esclarecedores.

E o telefonema pós-consulta? É instrumento muito usado por aqueles, hipocondríacos à parte, que entendem que a distância reduz o grau de compromissos e ameniza o impacto de certas queixas que podem originar investigações atemorizantes.

A comunicação entre pessoas envolve mensagens nem sempre explícitas que reclamam decodificações para identificar seu conteúdo tão ou mais significativo do que a 
comunicação formal. É o caso de atos falhos, bloqueios súbitos, variações inesperadas do assunto, mudanças de postura que sinalizam a necessidade de se prestar atenção além da formalidade das palavras.

Quantas vezes o "terceiro ouvido" se presta como instrumento de reavaliação de uma impressão inicial, ao fazer voltar à mente algum tempo depois, com seu real significado, uma frase, uma palavra dita de modo dissimulado, aparentemente destituída de importância.

Em suma, anamnese é monólogo, é diálogo, é ajustes incessantes tanto mais exatos quanto mais estreitada a relação médico-paciente.

Neste processo de liberação gradual das queixas, de como os sintomas de fato se manifestam, é interessante mencionar o papel do acompanhante. A sua presença representa com freqüência o guardião da transparência dos fatos e o vigilante da memória. Todavia, também pode ser causa de inibições (aspectos sexuais, por exemplo) ou omissões (para não preocupar o acompanhante, por exemplo) por parte do paciente.

Muitas vezes nos deparamos com uma atitude de contragosto à pretensão de esmiuçar dados da anamnese por parte do paciente ansioso por uma opinião sobre exames trazidos. Insistir ou se adaptar não se excluem necessariamente, a resolução da alternativa dependerá muito da sensibilidade de momento.
Em situações de emergência, a anamnese pode ser sumária, inclusive limitada à queixa principal, ou mesmo nenhuma. A dinâmica é essencialmente ditada pelas circunstâncias, mesclando procedimentos diagnósticos e terapêuticos e tem sido objeto de atualizados projetos de normatizações.

O exame físico representa momento idealizado em que o médico vai de fato "ver o que está acontecendo". Os princípios do exame físico continuam inalterados, não estão em discussão e não há porque se sentir desobrigado deles.

Cada profissional o utiliza do modo como melhor entende, mais completo ou mais limitado ao interesse da especialidade. Sinais tanto os em reciprocidade com a anamnese quanto os configurados como achado persistem pilar insubstituível.

O resultado da anamnese e do exame físico é o mesmo diagnóstico clínico de sempre, a busca de uma síntese apesar de antagonismos e contradições.

Ao diagnóstico clínico se sucede o diagnóstico integrado que a ele se superpõe, o amplia ou se antagoniza parcial ou totalmente, segundo o princípio de um olho no paciente e outro nos exames. Importante é reconhecer o que é incontrariável e usá-lo como maior força de orientação diagnóstica. Qualquer entendimento diverso constitui deformidade inaceitável do exercício profissional. 